\section{MEETINGS AND COURSES}

Annual Courses

Title: Courses in Sexual and Reproductive Health. Venue: University of Warwick, Warwick, UK. Details: See display advertisement on inside back cover.

\section{Annual Course}

Title: Diploma in Family Planning and Reproductive Health Theory Course. Venue: Fieldhead Hospital, Wakefield, UK. Details: See display advertisement on page 69 .

\section{Throughout 2004}

Title: Various Courses including the STIF Course and DFFP organised by The Sandyford Initiative. Venue: Various, UK. Details: See display advertisement on page 71.

\section{Throughout 2004}

Title: Courses on Current Issues in Sexual and Reproductive Health organised by The Margaret Pyke Memorial Trust. Venue: London, UK. Details: See display advertisement on page 70

\section{Throughout 2004}

Title: Various Courses on Family Planning and Reproductive Health Care organised by the Mersey Region Group for Family Planning Training. Venue: Various. Details: See display advertisement on page 70

\section{Throughout 2004}

Title: Scottish Family Planning Medical Society One-Day Educational Meetings on Family Planning and Reproductive Health Care Topics. Details: See display advertisement on page 69

\section{7-11 February 2004}

Title: East Meets West. Venue: Chiang Mai, Thailand. Details: A stimulating, educational conference on sexual and reproductive health care for all health professionals working in the field. Information: Dr Richard Burack at Siam Care UK. Tel: +44 (0) 1992 525158. Fax: +44 (0) 1992 525159. E-mail: siamcare@aol.com

\section{March 2004}

Title: 115th Meeting of the Northern Interbranch Group. Venue: Leeds Medical School, Leeds, UK. Details: A 1-day update for members and guests on reproductive and sexual health. Accreditation: PGEA and FFP applied for. Information: Dr Myra Holbrook, 20 Grange Close, Skelton, York YO30 1YR, UK. Tel: +44 (0) 1904 470674. E-mail: myra.holbrook@ york.nhs.uk.

\section{March 2004}

Title: Spring Meeting of the NW Society of Sexual Medicine and Family Planning. Venue: Maritime Museum, Albert Dock, Liverpool, UK. Details: Two sessions: morning 0945-1300, afternoon 1400-1615. Topics include: natural family planning, postcoital and intermenstrual bleeding problems; interactive IUT session with questions and answers; medical foundation for care of victims of torture. Accreditation: PGEA and FFP. Information: Miss Mavis L Barnard, 7 Regent Road, Chorley PR7 2DH, UK. Tel: +44 (0) 1257267657.

\section{March 2004}

Title: Young People's Sexual Health. Venue: The Conference Centre, Stirling Royal Infirmary, Stirling, UK. Details: A 1-day conference run by the Scottish Family Planning Medical Society covering all aspects of sexual and reproductive health issues for young people. Accreditation PGEA and FFP applied for. Information: Tracey Chiverton, Clinical Effectiveness Unit, Room 63, Aberdeen Maternity Hospital, Cornhill Road, Aberdeen AB25 2ZL, UK. Tel: +44 (0) 1224 553623. Fax: +44 (0) 1224 551081. E-mail: t.chiverton@abdn.ac.uk.

\section{March 2004}

Title: Update in Women's Health. Venue: Postgraduate Centre, Freeman Hospital, Newcastle-upon-Tyne, UK. Details: Open to al doctors and health care staff working in or with an interest in family planning and reproductive health care, organised by Newcastle Contraception and Sexual Health Service. Accreditation: CME and PGEA. Information: D Margaret Hogarth, Newcastle Contraception and Sexual Health Service, Graingerville Clinic, Newcastle General Hospital, Westgate Road, Newcastle-upon-Tyne NE4 6BE, UK. Tel: +4 (0) 191219 5239. Fax: +44 (0) 191219 5232. Email: margaret.hogarth@ newcastle-pct.nhs.uk.

\section{March 2004}

Title: 'Sex and Secrets': Child Protection and Confidentiality. Venue: University of York, York, UK. Details: This 1-day multidisciplinary conference would like to invite doctors and nurses working in the fields of contraception, genitourinary medicine, paediatrics, genera practice, school health, the police and lega professions, social services staff and those working in the voluntary sector. Topics include the legal framework, particularly the Sexual Offences Bill; sexual abuse in context with othe forms of abuse; forensic medicine and case discussions. Accreditation: FFP, PGEA and RCOG. Information: For further information visit www.ffprhc.org.uk or contact the Conference Secretariat, Child Protection 2004, Meeting Makers, Jordanhill Campus, 76 Southbrae Drive, Glasgow G13 1PP, UK. Tel: + 44 (0) 141 434 1500. Fax: + 44 (0) 141434 1519. E-mail childprotection2004@meetingmakers.co.uk Also see display advertisement on page 69

\section{2-4 April 2004}

Title: Weekend Family Planning Theory Course for Doctors. Venue: Northwick Park Hospital, Harrow, UK. Details: This 3-day course conforms to the new DFFP syllabus. It is also suitable for updating and is a useful update for al doctors who provide contraception and sexua health care. Accreditation: DFFP and PGEA applied for. Information: Valerie van Leeuwerden, Family Planning Office, Level 5 Maternity Block, Northwick Park Hospital, Watford Road, Harrow, Middlesex HA1 3UJ, UK. Tel: +44 (0) 208869 3127. Fax: +44 (0) 20 8869 2903. E-mail: bela.reed@nwlh.nhs.uk.

\section{April 2004}

Title: Induced Abortion (Royal Society of Medicine Sexual Health and Reproduction Medicine Section Meeting). Venue: The Roya Society of Medicine, London, UK. Details: This all-day meeting reviews the current state of play in induced abortion from both social and clinical points of view. New publications will be announced including a preview of the revised RCOG guideline. Other topics include: services outside hospital settings; innovations in clinical care; and the contribution of nurses and doctors' training. Accreditation: CME/CPD, RCOG, FFP and PGEA. Information: Nikki Collett, The Royal Society of Medicine, 1 Wimpole Street London W1G 0EA, UK. Tel: +44 (0) 207290 3937. Fax: +44 (0) 207290 2989. E-mail: sexual.health@rsm.ac.uk.
24 April 2004

Title: 'Nuts and Bolts of Contraception and the Menopause: An Update'. Venue: Sandwell General Hospital, Birmingham, UK. Details: The first joint meeting of the West Midlands Menopause and Family Planning Doctors' Associations, planned to include updates of perimenopausal contraception, HRT controversies, IUDs and the Sexual Offences Bill. Further information will be available from the website at www.wmafpd.org.uk and booking forms can be downloaded from early February 2004. Accreditation: 5 hours FFP, including 1 hour IUT, applied for. Information: Dr Ruth Fear, 71 St Helen's Road, Solihull, West Midlands B91 2DB, UK. Tel: +44 (0) 121705 5146 (evenings). E-mail: symposium@wmafpd. org.uk

\section{1 and 15 June 2004}

Title: STIF Course. Venue: Chancellor's Conference Centre, Manchester, UK. Details: The aim of the course is to equip participants with the basic knowledge, skills and attitudes of the effective management of STIs outside the GUM setting. Accreditation: FFP, PGEA, RCP and BASSH. Information: Irene Healey, Regional Training Department, The Palatine Centre, 63-65 Palatine Road, Withington, Manchester M20 3LJ, UK. Tel: +44 (0) 161434 8629. Fax: +44 (0) 161 448 1889. E-mail: i.healey@man.ac.uk.

\section{June 2004}

Title: FFPRHC Annual General Meeting. Venue: Edinburgh International Conference Centre, Edinburgh, UK. Details: For further information visit the Faculty website at www.ffprhc.org.uk. Information: Conference Secretariat, AGM 2004, Meeting Makers, Jordanhill Campus, 76 Southbrae Drive, Glasgow G13 1PP, UK. Tel: + 44 (0) 141434 1500. Fax: + 44 (0) 141434 1519. E-mail: agm2004@ meetingmakers.co.uk.

\section{3-26 June 2004}

Title: 8th Congress of the European Society of Contraception. Venue: Edinburgh International Convention Centre, Edinburgh, UK. Details: A holistic approach to sexual health. Information: European Society of Contraception, ESC Central Office, Orga-Med Congress Office, Essenestraat 77, B-1740 Ternat, Belgium. Tel: +32 25820852 . Fax: +32 2582 5515. E-mail: orgamed.ria@ pandora.be. Also see display advertisement on page 72 .

\section{November 2004}

Title: Advances in Abortion Care. Venue: Royal College of Obstetricians and Gynaecologists, London, UK. Details: Full-day meeting to review and compare developments in abortion care in the UK and overseas. Accreditation: FFP, CME, PGEA and RCN applied for. Information: Alex Sherriff, bpas Head Office, Austy Manor, Stratford Road, Henley in Arden B95 6BX, UK. Tel: +44 (0) 1564793225 . Fax: +44 (0) 1564 792702. E-mail: alex.sherriff@bpas.org.

There is a charge of $£ 50.00+$ VAT for each meeting/course publicised in this section of the Journal. This will guarantee inclusion in the issue requested. For guaranteed inclusion in the April 2004 issue all course details should be with Sarah Monger by 27 February 2004. For a booking form please contact Sarah Monger at PMH Publications, PO Box 100, Chichester, West Sussex PO18 8HD, UK. Tel: +44 (0) 1243 576444. Fax: +44 (0) 1243 567456. E-mail: adsales@pmh.uk.com. 
MARGARET PYKE MEMORIAL TRUST

The Advancement of Medical Education \& Research in Sexual and Reproductive Health

\section{UP-DATE COURSES 0N} SEXUAL \& REPRODUCTIVE HEALTH

\section{- for general practice -}

Regent's College, Inner Circle, Regent's Park, London NW1 4NS

\section{IMPORTANT DIARY DATES FOR 2004}

- Friday 12th March

- Friday 21st May

- Friday 16th July

- Friday 12th November

- Friday 10th December

These advanced up-date courses will have $5 \frac{1}{2}$ hours of FFP and PGEA accreditation applied for as well as 2 sessions of study leave from the ICPG

The courses are all designed to offer latest information and current thinking in a variety of topical issues in sexual and reproductive health care. Come and enjoy an interesting and informative day of lectures given by leading specialists in their

respective fields. Programme details/application forms will be available on our website early in 2004 .

\section{MARGARET PYKE MEMORIAL TRUST}

The Advancement of Medical Education \& Research in Sexual and Reproductive Health with

\section{Camden WTHS \\ Primary Care Trust}

Basic Theoretical Courses for the Diploma of the Faculty of Family Planning (DFFP) are scheduled for the following dates in 2004:

18th, 19th \& 20th February (no available places) 12th, 13th \& 14th May

22nd, 23rd \& 24th September 1st, 2nd \& 3rd December

An Instructing Doctors' Course will be held on 9th, 10th and 11th June

If you would like to receive details of the programmes as soon as they are published, or

for further information, please contact:

Rosemary Massouras, Margaret Pyke Centre,

73 Charlotte Street, London W1T 4PL

Tel: 02075303619 / 02074368390 ,

email: mpmttraining@hotmail.com www.margaretpyke.org
MERSEY REGION GROUP FOR FAMILY PLANNING TRAINING

(The University of Liverpool)

will be holding the following courses \& conferences:-

Faculty of Family Planning and

Reproductive Health Care

Diploma Basic Theoretical Course

(or for updating purposes for Doctors and Nurses)

Mon. Tues. \& Wed. 22nd 23rd \& 24th March 2004

Mon. Tues. \& Wed. 28th 29th \& 30th June 2004

Mon. Tues. \& Wed. 27th 28th \& 29th September 2004

Mon. Tues. \& Wed. 6th, 7th \& 8th December 2004

\section{ANNUAL FAMILY PLANNING UPDATE DAY}

Thursday, 22nd April 2004

The Hanover International Hotel, Stretton, Warrington

Faculty of Family Planning CME approved

\section{MFFP PART 2 PREPARATION} COURSES

Thursday, 11th March 2004

\&

Thursday, 29th April 2004

Liverpool Women's Hospital NHS Trust

\section{ANNUAL WOMEN'S HEALTH ISSUES CONFERENCE}

Thursday, 7th October 2004

The Hanover International Hotel,

Stretton, Warrington

Faculty of Family Planning CME approved

For further information and if you would like to be added to our mailing list please contact:-

Carmel Farrell

Mersey Region Group for Family Planning Training

Liverpool Womens Hospital NHS Trust

2nd Floor, Crown Street, Liverpool L8 7SS

Tel: 0151-702 4102

Fax: 0151-702 4039

email: carmel.farrell@lwh-tr.nwest.nhs.uk (9.15a.m.-3.15p.m. Monday-Thursday) 